\title{
Identity Encounters in Public Spaces-Military Service as a Legally Binding Public Space. The Case of Women's Singing in the Israel Defense Forces
}

\author{
Shani Umiel-Feldman
}

Department of Political Studies, Bar Ilan University, Ramat Gan 5290002, Israel; umiel.shani@gmail.com

Received: 25 February 2020; Accepted: 26 March 2020; Published: 30 March 2020

\begin{abstract}
The term 'Public Sphere' is used to distinguish it from the private. Here, we will use the term 'Public Spaces' to distinguish between various types of public spheres, differing from one another not only in their controlling identity, but also in the level of obligation to be in them and the extent in which they demand obedience from their participants. The new typology proposed in this paper conceptualizes the Israel Defense Forces [IDF] as a legally binding Public Space, using the case study of the Jewish religious law prohibiting Orthodox men to listen to a woman's singing voice. This prohibition has sparked a strong public controversy and ongoing clashes between the army and religion. The case study illustrates a wide range of confrontations over the identity of the IDF's space. While examining similar cases in other armies around the world, the paper presents a model explaining the terms and conditions for disputes on the nature of Public Spaces around the world, and when to expect confrontations between identities in different Public Spaces. Finally, the paper attempts to predict the extent and scope of such confrontations, on four dimensions: (a) The level of obligation to be in the Public Space; (b) the level of greediness of the Public Space; (c) the level of heterogeneity of identities within the Public Space; and (d) the level of personal identity greediness of persons and groups whose identity differs from the hegemonic identity in the public space.
\end{abstract}

Keywords: Legally binding Public Spaces; identity encounters; Jewish Law; IDF; women's singing; MFSs; religious diversity

\section{Introduction}

Encounters between cultures and identities in Public Spaces are at the center of global public and political discourse. In this global era, democratic States whose development relied on secularization are characterized by a type of multiculturalism in which certain cultures not only do not assimilate, but actively seek cultural separateness and preservation. This reality ignites struggles between differing identities and poses a challenge for theories assuming that secularization would reduce the power of religion and its effect on politics (Haynes 2005, 2006, 2011). A central example of this phenomenon is the Burqa Ban that commenced in France and gradually spread throughout Europe (Thompson 2019b). ${ }^{1}$ In Israel, a country that has always had to cope with struggles regarding the place of religion in the public space (Ben-Porat 2013) ${ }^{2}$, an especially important battle ground is the military space, which is the greediest and most legally binding compared to all other Public Spaces in the country.

1 Thompson's comprehensive paper describes the European case in which countries characterized by strong national identities are coping with differing religious identities in their public spaces such as crosses in classrooms in Italian public schools and the Swiss ban on building minarets on Mosques (Thompson 2019b).

2 The Halacha (Jewish law) prohibits any labour, work, commerce, and transportation on the Sabbath. In Israel there are laws pertaining to the Jewish nature of the public space: Israel's 'Work and rest hours' law' prohibits the employment of Jews on the Sabbath. 
Compulsory militaries around the world are heterogenic meeting points for persons originating from diverse populations and identities. In the public discourse, they are included under the expansive definition of 'the public sphere', which also includes city squares, parks, or hospitals. However, clearly each of these, and especially the military space, have unique characteristics from which specific laws, rules, and behavioral norms are derived. The theoretical assumption on which this paper relies is that the field of study of the Public sphere in its territorial-physical sense, lacks a methodical theoretical conceptualization distinguishing between different types of Public spheres.

The current paper proposes a new conceptualization for compulsory military service as a 'legally binding public space', using a qualitative analysis of the sequence of events and public discourse that unfolded on the question of women's singing ${ }^{3}$ in the IDF as an example of a range of confrontations on additional topics pertaining to the IDF's space. ${ }^{4}$ In this paper, we present a new theoretical model of identity encounters in Public Spaces, which is based on a Ph.D. dissertation ${ }^{5}$ that examined and surveyed dozens of case studies pertaining to women's singing in Israel, of which 35 cases were analyzed and presented. All cases were directly related to identity demands, raised between the years 2008-2016, on the formation of Israel's various public spaces in terms of the halachic (Jewish law) prohibition for men to hear women singing. The model (Figure 1) presents the integration and reciprocities between the different nature of public spaces and the differing and even contradictory nature of identities encountering one another within it as an explanation for the level of potential confrontation which may develop regarding the nature of the space.

\section{Women's Singing: Between Religious Prohibition and Central Cultural Status}

While Talmudic mentions on the prohibition to hear women singing includes a range of different opinions on its implementation, orthodox Jewish law explicitly prohibits a man from hearing a woman who is not his wife and is over 12 years old singing (see: Shulchan Aruch, Even Ha'ezer, 21:1). In Israel today this prohibition is upheld mainly by the ultra-Orthodox (Haredi) and the Zionist ultra-religious (Haredi-Leumi) streams. ${ }^{6}$ It should be noted in this context that in Israel, the Orthodox stream holds a monopoly over Jewish religious rules, in contrast to Diaspora Jewry, where other streams such as Conservative and Reform are recognized and widely accepted.

3 The Halacha (Jewish law) includes various prohibitions pertaining to contact between men and women. Men are forbidden from looking, hearing the singing voice, and being in a closed room with a woman who is not their wife. Over the last generations, these customs have been expanded and trickled into various public spaces, resulting in separation between men and women on public busses passing through ultra-orthodox neighborhoods, gender separation in academic studies by the establishment of separate programs for groups of ultra-orthodox students, and the demand not to hear women singing in public events (see Karmi and Shapira-Rosenberg 2012) Women's singing is very prevalent in the IDF (as will be further described below), and is therefore a challenging issue for some religious soldiers (for more on this see Berman 1980).

4 This case study is the most prominent in a list of identity struggles that include the dispute on joint military service for men and women (Levy 2010); struggles over the past decade within the IDF between the Education corps and the Military Rabbinate (Cohen et al. 2016); and the religionization discourse which began in 2010 on the empowerment of religious factors and their influence on the IDF. Yagil Levi's studies are the most identified with the 'religionization' term (see, for instance, Levy 2016, 2014), while Statman (2019) suggests that the religionization thesis should be rejected (For a discussion on the presence or absence of religionization in the IDF, see for instance Gal and Libel 2012). Other confrontations, such as stricter terms for growing beards-among the prominent external features of certain religions such as Judaism and Islam (Rosman-Stollman 2005, pp. 26-28, 33); the struggle for the right to express LGTB identities; and the struggle regarding women's service in combat positions in the IDF (and specifically in the armoured corps) are only some of the ongoing struggles over the identity of the IDF space.

5 This paper is based on the author's Ph.D. dissertation from Bar Ilan University: Umiel-Feldman, Shani-The Confluence of Identities in Public Spheres-New Conceptualizations: Women's Singing in Religious Zionism. Ph.D. dissertation. Ramat Gan: Bar-Ilan University (2016).

6 Religious-Zionism is comprised of identity groups differing from each other in their level of religious demands: While Haredi-Leumi/Torani have adopted stricter religious patterns, the Liberal/Modern Orthodox are less strict in following some patterns of the Halacha (Jewish law), and therefore hold relatively lower levels of identity greediness. Between these two extremes is the silent majority who follow mixed patterns according to circumstances and specific issues (Hermann et al. 2014). 
The halachic prohibition on women's signing was completely absent from mainstream Israeli discourse until about twenty years ago ${ }^{7}$ and completely absent from Israeli discourse until about a decade ago, when public debate on the matter erupted, even though the halachic prohibition itself had been well known. As can be seen from early training materials for religious soldiers (Cohen and Susser 2014) as well as from studies on religion and the military in Israel (Rosman-Stollman 2005; Kampinsky 2005; Cohen 1997,2001$)^{8}$, the topic was nearly absent from military and public awareness and received marginal or negligent attention, if at all. The public uproar at the center of the present study should be perceived vis a vis the strengthening of the religious aspect of the identity of a minority of religious soldiers pertaining to the Orthodox-nationalist wing, as most religious soldiers did not view this prohibition as part of their religious identity. Hence, the prohibition on hearing women's singing among some religious identities had been on a clear collision course with the IDF's daily reality, in which military bands have been at the forefront of Israel's emerging Hebrew song culture (Tessler 2007), and women's singing has always been a part of the IDF's public space, not only in official ceremonies, but also in recreational and entertainment events.

\section{Confrontation, Accommodation, and a Culture War Atmosphere: Women's Singing in the IDF}

The first documented cases of soldiers leaving events during women's signing in the IDF occurred in 2008, but were published only in 2009 following a second such event. ${ }^{9}$ The first actual confrontation occurred in 2010, while during a memorial for the late Prime Minister Yitzhak Rabin, a number of cadets in Bahad 1 officers' training course left the ceremony due to women's singing. When ordered by their commander to return, most of them did, except for three who refused and therefore were sentenced to six days of military incarceration (Breiner 2010). Most responses to this event took place in the media, and specifically in religious Zionist sectoral media channels, but the matter was also discussed in the Knesset (Israel's Parliament). The two main response to this discussion strongly illustrate the two extremes of the public discourse on this topic (which will be described below regarding the 2011 event). The first is the response of Knesset member Amsalem of the Shas ultra-orthodox party, who claimed that the order to return is a black flag. The second is the response of then Minister of Defense and Knesset Member Matan Vilnai, who argued that military discipline should be top priority, and therefore these cadets cannot be commanders in the army and moreover should have been expelled from the course rather than only serving a short prison sentence (see Knesset 2010, p. 16).

The second confrontation, occurring in 2011, significantly aggravated the culture war atmosphere within Israel's public discourse: During a ceremony at the Bahad 1 officers' training course, two religious cadets declared that they would not be able to listen to women's singing. Their commanders instructed them not to leave the ceremony, but when the ceremony began, they rose to leave anyhow, along with a group of nearly 30 religious cadets, about one third of all religious cadets present. The battalion commander, Lieutenant Colonel Uzi Kliger, tried to stop them, stating that leaving would mean insubordination. The cadets, in turn, explained that "hearing women's singing is against the

7 Following the events that took place within the IDF, as discussed later in the paper, a survey was published in 2016 regarding trends involving hearing women's singing in the Religious Zionist sector, showing that a large majority of men in this sector do listen to women's signing and do not leave events in which women sing ("Let me hear thy voice" 16 Sept. 2016: 20). The data collected illustrate the internal division within religious Zionism into identity groups differing from one another on their level of identity greediness: On one side of the continuum are Orthodox-nationalists, adopting strict halachic behavioral restrictions, while on the other side are liberal religious groups characterized by lower levels of adherence to the Halacha, and therefore a relatively low identity greediness. Between these two poles is a silent majority, characterized by mixed, topical, and circumstantial patterns of behavior (Hermann et al. 2014).

8 For more on this topic see (Umiel-Feldman 2016, pp. 127-29).

9 In an article published on 2009 in the IDF's weekly magazine 'Bamahane', the event in which soldiers left events in which women singers took part, as a "situation taking place in unit ceremonies", noting two cases in which the IDF took no significant action or position towards the soldiers who left the hall (Saar and Kosti 2009). The reason for this had been apparently the nature of the events, their uniqueness, and the fact that the soldiers in question, who were in reserve and compulsory duty, were soldiers towards whom the system's level of greediness was relatively low compared to the level of greediness towards cadets in officers' training course. See more on this in the following pages. 
Halacha". The battalion commander was not convinced, saying: "You are insensitive and have no respect towards the [women] singers, and I cannot allow you to be officers. Those who are insensitive cannot distinguish between a child bringing medicine to his family and a terrorist in Lebanon. He would shoot a child." (Attali 2011; Nahshoni 2011). The military space demands from its soldiers and commanders not only combat skills, but also moral ones. Clearly the demand to consider matters beyond the halachic prohibition is in fact a demand to resolve the gap between subordination to the Halacha and to the laws of the military space. Finally, of a total of 93 religious cadets present, only nine actually left the venue (Cohen and Susser 2014) ${ }^{10}$. They were trialed, and four were consequently dismissed from the course: Two who approached their commanders but then ignored the clear order given, and two who refused to express regret for their action. Hence, all of them refused to show their subordination to military discipline and chose to act according to the rules of their distinct identity ${ }^{11}$.

This event led to a general public uproar with responses from all sides of the political arena, including the military, the rabbinate, the media, and society in general. Representatives of the army, general media, and the secular public complained of the 'exclusion of women' and 'religionization' of the IDF. The question of authority was discussed — who are religious soldiers obligated to obey-their commander or their rabbi? In parallel, some rabbis and parts of the religious-Zionist population complained of 'anti-religious coercion', of undermining the honor of the Tora, and of illegal orders being issued against religious law (Halacha). ${ }^{12}$

The range of differing positions presented in the public discourse during 2011 on the topic of women's singing in the IDF is too expansive for our present discussion. However, we will shortly illustrate the two extremes: On one side of the continuum is the most extreme response of the discourse, the position of Rabbi Elyakim Levanon, who said that Rabbis should instruct their students to step outside when women are singing, "even if a shooting squad is standing outside", and that he would advise his students not to serve in the IDF at all (Ettinger 2011). On the other side of the continuum is the position that soldiers who refuse to hear women singing are not worthy of being IDF commanders (as can be seen in the words of lieutenant colonel Uzi Kliger, mentioned above).

The first confrontation led to a resolution attempt within the IDF, by which religious soldiers would be present in ceremonies in which men and women sing together. This resolution relied on a halachic interpretation that the prohibition applies only to women singing solo. And in fact, until 2011, there were no further disputes on the matter (Harel 2011b).

\section{A Growing Culture War Atmosphere in the IDF}

As said, women's singing is only one case in a range of confrontations resulting from religious identity demands towards the binding and greedy space ${ }^{13}$ (more on these concepts will be explained later in the paper in the context of the proposed model). Moreover, this confrontation has raised to public agenda the broader issue of the exclusion of women from the public space in other spaces, such as gendered segregation in public transport. ${ }^{14}$ Many public figures, including Prime Minister Netanyahu and President of the State at the time Shimon Peres, publicly declared the exclusion of women to be wrong and contrary to the values of the State of Israel (Shalev 2011). ${ }^{15}$ The general atmosphere following the 2011 event was so heated, that then Secretary of State Hilary Clinton declared

10 This data corresponds with that of the most updated survey held on this topic (see footnote 8).

11 Later on, one of the expelled cadets appealed to the Supreme Court, but the latter refused to intervene on the matter.

12 This included an internal religious discourse on the validity and status of the religious prohibition on hearing women's singing, and how to deal with the matter.

13 See footnote number 5.

14 In Israel, there are "Mehadrin" bus lines in Haredi (ultra-orthodox) neighborhoods on which women are asked to sit in the rear of the bus due to 'modesty' laws (see footnote number 4). These busses are also used by non-Haredi passengers, which often results in confrontations which even reached a Supreme Court resolution (for more on this topic see Karmi and Shapira-Rosenberg 2012).

15 For more on this topic see (Umiel-Feldman 2016, pp. 137-40). 
that she is worried about the public atmosphere in Israel regarding the exclusion of women from public spaces in general, including the avoidance of hearing women's singing in the IDF, which is reminiscent, according to her, of the situation in Iran (Benhorin 2011). Many similar expressions illustrate the culture war atmosphere that was exacerbated following the event of 2011, including by proponents of the hegemonic IDF identity, such as General Yishai Bar, who said that this event marks the IDF's becoming the frontline of the war of religion (Harel 2012), as well as from holders of religious identities who felt that the IDF is fighting against its religious soldiers, seeing them as second class compared to ultra-religious soldiers who serve under strict gender separation conditions. Rabbi Shmuel Eliyahu, identified as one of the most important Orthodox-nationalist Rabbis, said that it is a mitzvah (religious duty) to disobey an order to hear women's singing: "Even soldiers who are normally lenient ... cannot adhere to this demeaning command which implies that 'you are second class'." (Rosenbaum-Rotenberg 2012).

Between the two main confrontations on the topic of women's singing in the IDF, we note the strengthening of a culture war atmosphere in the army, in a letter issued by Major General Zamir, then head of the IDF's Manpower Directorate, to then Chief of Staff lieutenant general Benny Ganz, parts of which were published in the media. In his letter, Major General Zamir writes that the IDF is a national institution coping with a culture war taking place within it and therefore must 'draw a stop line' so as to prevent a situation in which it is unable to achieve its military sims. He further wrote that "The IDF is a critical arena in the struggle for the nation's character and therefore the norms set by it will have a huge impact on the future of the State." (Harel 2011a). The letter evoked angry responses among religious Zionist groups who felt that the IDF is fighting against religious identity and specifically against religious soldiers serving in it. This may well have triggered elevated religious demands among the Religious Zionist community in general, expressed in the behavior of a number of religious cadets during the 2011 occurrence. These demands among the religious-Zionist community reached a high chord in 2016 following years of identity struggles over the Jewish character of the IDF and the question of religionization within its bounds. A survey published that year found that $65 \%$ of religious-Zionists feel that "there is a deliberate attempt to undermine the impact of religious soldiers and their presence in the army" (Vaystoch 2016).

At the end of 2011, then Chief of Staff Lieutenant General Benny Ganz decided that all IDF soldiers would be required to participate in official ceremonies, even if these include women singers, but in entertainment and recreational events they would be able to choose not to participate (Haaretz 2011). Thus, even within the IDF's compulsory and generally greedy space, there are 'sphericules' that differ from one another in their level of greediness towards those serving in the IDF, with an intuitive attempt to differentiate between different identities as a way of regulating potential conflicts and avoid any friction resulting from encounters between them in such a space. The Chief of Staff noted that it is fitting that the IDF's legacy, also in the area of Israeli musical culture, would live on (ibid.). His words clearly point to a decision to maintain the identity of the compulsory, greedy, and heterogenic space, even in the wake of a highly potent event. This resolution was included in 'the Joint Service Ordinance' of 2016, and served as a trigger for continued heated confrontations on this topic in other public spaces $^{16}$, as well as on similar topics within the military space ${ }^{17}$, in line with the circular resolution and confrontation model (Figure 2), Public Spaces and Public Spheres in the literature.

Habermas, among the main contributors to the literature on Public Spheres (Habermas 1989; 1991), conceptualized the Pubic Sphere as pertaining to public discourse. However, the theoretical

16 While within the compulsory IDF space recurring rounds of confrontation have been ultimately resolved by orders issued by the Chief of Staff. In other public spaces, such confrontations are elevated to public awareness in specific times of the year such as in the case of municipal memorial ceremonies, where confrontations occur every year during the period of the national commemoration events in May and in October-November. For more on this topic see (Umiel-Feldman 2016, pp. 226-34).

17 For instance- - the question of women's service in combat positions and joint service for women and men. 
discussion on Public Spheres that relies on Habermas, his successors, and critics (for instance, Dahlgren 1993; Fraser 1990, p. 67; Orbe 1998; Gitlin 1998; Liebes et al. 1996; Widdersheim and Koizumi 2016; Widdersheim 2017, and others), serves the topic of identity encounters in a limited manner-that which pertains to the physical-territorial sense of the Public Sphere. This is an essential distinction for understanding the types of encounters and reciprocities between differing identities within different Public Spheres. ${ }^{18}$ This idea is explained by Thompson, who wrote that while Habermas' definition of Public spheres is the most well-known, it does not define the attributes and borders of the physical public space, and that only a definition that includes this aspect would enable reaching clear conclusions as to the nature and scope of the rights that people should receive in such territory (Thompson 2019a).

While the relevant discourse focuses on the topic of religious identity in the Public Sphere mostly through a prism of balancing and weighing of rights from the viewpoint of political or legal thought, the current paper attempts to propose a new tool for defining and characterizing different Public Spheres based on the level of obligation to be in them and on their level of greediness. Such a tool may shed light on different types of religious responses to conflicts that arise as a result of participation in the general secular Public Sphere. ${ }^{19}$

Other relevant studies examine the distinction of the Public Sphere from the Private one (for instance: Benhabib 1992; Pateman 1989; Pitkin 1981; Weintraub 1997; Lewis 1992; Gal 2002), the distinction between publicly or privately owned Public Spheres (Németh and Schmidt 2011; Chiodelli and Moroni 2014), its urban aspects (De Certeau 1984; Lefebvre [1947] 1991; Park [1925] 1984; Simmel [1903] 2002), its social ones (Elden 2004; Shields 1999; Soja 1989; Lefebvre [1947] 1991; Harvey 1973, 1996), and its cultural ones (for instance: Claval et al. 2003; Alexander 1988; Bourdieu 1977).

Other studies are more relevant to the new conceptualization proposed here, dealing with the need to differentiate between different types of Public spheres in the context of cultural diversity (Meir and Karplos 2015) and to regulate the tensions arising from religious expressions within them (Thompson 2019a, 2019b). Other important and relevant studies discuss the question of the personal freedom to express religious attributes in the Public Sphere, as in the European case (Motilla 2013; Mancini 2013). Our model also focuses on the question of religious expressions limiting other individuals in the Public Sphere, such as gendered separation resulting from religious laws of modesty ${ }^{20}$, and the question of the level of obligation, necessity or voluntarism of individuals to be in a certain Public sphere.

\section{A Model of Identity Encounters in Public Spaces}

The new conceptualization of Public Spaces proposed in this paper maps and analyzes the various conditions for encounters between different identities and their reciprocal relations within the same Public Spaces, in order to answer the question: What are the conditions, processes, and factors that increase or decrease the potential for eruption of confrontation between identities in the different Public Spaces?

The underlying assumption is that the main factor for feasibility of a confrontation and its extent is the motivation among culturally distinct groups and the individuals belonging to them to form the Public Space according to their beliefs and life styles.

The main argument is that when (1) the public space obligates individuals to be in it; and (2) the public space has high levels of greediness towards the individual; and (3) the human composition is

18 It should be noted that in Hebrew the term 'Merhav' stands for either 'Sphere' or 'Space' (as in 'public sphere' or 'public space'). However, as mentioned, both forms are used in the literature to describe the physical area. Mitchell (2003) proposes to view the public area as "space" — a place in which to protest against exclusion from the public sphere. For more on the distinction between sphere and space see (Low 2017).

19 This is in contrast to responses pertaining to more homogenous cultural 'sphericules', such as the religious neighborhood, village, or city in which the population is religiously homogenous. In Israel there are ultra-orthodox cities such as Bnei Brak and Haredi neighborhoods in Jerusalem such as Mea She'arim, which are a public 'sphericule'. However, a cultural spherical can also be topical, such as a chain of private Muslim schools in France (Hanafi 2019).

20 See footnote numbers 4 \& 15 . 
increasingly heterogenic in terms of the range of identities in the space; and (4) the individual and/or the group are characterized by high identity-based greediness that is opposed to the identity of the majority-so grows the potential for confrontation over the nature of the space, due to the increasing probability for attempts by those possessing the more highly greedy identity to form the public space in a way that would suit their needs and enable them to be in the space without it challenging their identity. Below we present the four dimensions of the model, which essentially are the four factors differentiating between different types of Public Spaces.

\subsection{The Level of Obligation to Be in the Space}

The extent in which the individual is obligated to be in the public space is a component that is nearly absent from attempts to define Public Spaces in the relevant literature. This component can be seen as a continuum of possibilities, with binding spheres being on one end of the continuum, and voluntary spheres on the other. Between these two spheres are various levels of obligation to take part in different types of Public Spaces. The basic assumption is that if the individual must be in a certain space, he will aspire for the space to suit his identity, as if he is not obligated to be in a space that contradicts his identity, surely he would choose not to be in it. Considering the compulsory spheres, as opposed to voluntary ones ${ }^{21}$, we distinguish between three types of obligation: ${ }^{22}$ The Essential sphere ${ }^{23}$ the Symbolic sphere ${ }^{24}$ and the sphere on which the current paper is focused-the Compulsory sphere: A space in which the individual is obligated to be by law. Israel's conscription law makes the IDF a compulsory sphere. The State obligates the individual to be part of greedy Public Spaces in terms of the duration of the required stay (the model's level of greediness component will be further discussed below), such as the IDF, where compulsory service is 32 months for men and 24 months for women, or the education system in which students take part most hours of the day. The State, therefore, should be expected to create suitable conditions within such Public Spaces, to avoid challenging or damaging the identity of the individual. ${ }^{25}$ The complex reality, however, offers the individual a range of compulsory spaces with differing levels of compulsion to be in them. However, contrary to a temporary spaces, in which the individual is obligated to be for only a short while, such as the duty to report to a governmental agency to perform some bureaucratic task or other, the IDF is a public space characterized by the highest level of obligation in the Israeli case, not only due to the legal obligation to be in it, but also because of the obligation to be in it permanently for a very long period of time.

On the other side of the continuum, there is the voluntary sphere, where the individual has no obligation whatsoever to be in, and participation in it is the result of the individual's choice to do so.

21 Perez (2019) defines military institutions in democratic states as "Non-voluntary" and in fact refers in this term to the nature of the military institution, which does not allow the person to partake, for instance, in recreational activities that extend beyond the structured and busy military schedule routine. Thus, if the public space fails to provide religious services to those in it, this would be perceived as if the public space prohibits any religious activity within its borders. Hence, Perez points to the level of greediness asserted by the public space on its participants (see below), while the typology presented in the present paper distinguishes between the obligation to be in the public space and the greedy nature asserted over participants - as two distinct dimensions.

22 Examples of other types of binding public spaces will be presented in future studies, in preparation.

23 Essential spaces are those which are essential for daily life, such as hospitals, or government agencies such as Income Tax that provide irreplaceable services.

24 Note that what I refer to as 'the Symbolic sphere' differs from other concepts pertaining to symbolism, religion, and public space. Gavrilovic and Dordevic (2018) describe how religion takes over the secular space by symbolic means such as the use of the educational system and immersion of patriarchic approaches in society. The symbolic space. which is part of the model presented in this paper. is in itself the symbol and therefore potential ground for confrontation over the limits of its identity. For instance, the Western Wall in Jerusalem, perceived as a unique and sacred place, is the focus of an extensive identity struggle for its definition (Jobani and Perez 2014).

25 This conclusion corresponds with that of Perez (2019), who believes that in order to protect soldiers' religious freedom within the military framework and to allow them to pray and practice their religion, the army must provide them with due space and time as well as accessibility to religious personnel and means such as prayer books. 
Under this category are all public spaces in which the person has no legal obligation, necessity, or need to be in. These would mainly be spaces that include recreational and entertainment activities. ${ }^{26}$

Thus, the higher the level of obligation to be in a certain space, the higher the confrontation potential. ${ }^{27}$ When the level of obligation is low and the presence voluntary, individuals and groups are able to overcome identity gaps by simply not being in the same space. Conversely, the obligation to be in a certain space increases the potential for confrontation as there is no way to avoid being in the space together.

\subsection{The Level of Demands Made by the Public Space}

This term is taken from Coser's Greedy Institutes theory (Coser 1974, pp. 4-8). According to Coser, a greedy institute expects total loyalty from the individuals belonging to it, while relying mainly on elements of emotional, cognitive, mental, and cultural commitment and a partial or symbolic separation from the environment. Rosman-Stollman $(2005,2014)$ expanded the concept of greedy institutes to the context of religion and the military, showing the need for mediating institutions for reducing the strains and gaps between the two. ${ }^{28}$ In this proposed model, the level of demands made by the public space can be divided into two types of demands:

Practical greediness: This is the extent in which the space dictates the daily agenda of its participants and obligates them to conform to a list of compulsory rules of conduct. The army is a greedy space which dictates not only a strict agenda, but also rules of appearance and conduct, and the duration of the stay within its boundaries is normally a long one (Rosman-Stollman 2005, pp. 71-74, 82-86). It should be noted in this context that even within the army there are different levels of practical greediness: The level of greediness of a combat officer's course is not comparable to that of a rear office position in an open base. However, the soldier serving in a rear unit and the combat soldier both serve mandatory service and therefore the compulsion dimension is separate from the greediness one.

Identity greediness: These pertain to the nature of the space in terms of the hegemonic identity that controls it. ${ }^{29}$ High levels of identity greediness would be expressed in a clear agenda as to the desirable nature of the space, whether nationalistic and secular as in France (Kuru 2007), or 'Jewish' as arising from the law of the State of Israel regarding topics such as the nature of the Sabbath in the public sphere. In the case of the IDF, the greediness of the space is practical and identity-based, as it seeks to apply to the individual rules of conduct and values which may contradict his identity. The case study examined in the current paper-women's singing, illustrates this point well, as organized events expressing the identity of the military space include women, while certain identity groups view this fact as violating a religious prohibition, thereby increasing the motivation of individuals to form the Public Space in a way that would suit their own distinct identity.

It is important to note that although it may seem that the level of obligation to be in the space is in fact a further type of greediness of the space, in fact it is a completely separate category. As we have seen, within the IDF, which is a highly greedy space, there are different units characterized by different levels of greediness. However, both the combat soldier serving in a closed base and the soldier serving in a rear position at an open base-are both obligated to serve the same duration of time and to be in

26 For instance, restaurants, cinemas, parks, or a street used for walking, running, etc. It would be problematic to say that we could make do without any recreational or entertainment activities. However, in comparison to the purpose of other spaces and in relation to Maslow's hierarchy of needs, it would be possible to make do without them if they collided with other identity needs of the individual. The voluntary dimension is also expressed in a wide range of public spaces of this type.

27 On the topic of the two populations that are exempt from military service in Israel, Smooha and Lechtman (2015) argue that obligatory service for all Arab Israeli citizens is perceived as 'crossing a red line', while Bick (2015) believes that in a scenario in which service of ultra-orthodox women would be obligatory, this population would initiate civil disobedience steps.

28 In the model presented in the paper, military demandingness is expressed in the term 'identity greediness of the public space' while religious greediness is expressed in the term 'identity greediness of the individuals or groups towards the public space'.

29 Thompson believes it is important to limit the ability of a nation to express religion within the public spaces of its society. In the terms of our model, he believes in the need to limit the identity greediness of the space towards its inhabitants. 
the IDF's space. Therefore, we are dealing with a new and distinct component, which should not be included under the greediness category.

\subsection{The Level of Heterogeneity of Identities Among Individuals Towards the Public Space}

Multi-culturalism in its basic definition is a state in which two or more cultural or identity groups occupy a certain public space (Parekh 2000). A high level of heterogeneity would mean a number of cultural groups with opposing identities being together in a given Public Space ${ }^{30}$ while the opposing end of the continuum would be a high level of homogeneity of a single cultural group in a space that will be referred to as 'sphericule'. The higher the level of heterogeneity within a space, and the more opposing and differing the identities it comprises, the higher the confrontation potential for the definition of the character of that space. ${ }^{31}$

\subsection{Identity Greediness of the Individuals in the Public Space}

The level of identity greediness of individuals or groups towards the public space is a key point in the question of motivation for forming the character of public spaces. Identity, be it as it may ${ }^{32}$, has a greedy nature in varying levels. Statman and Sapir (2013) distinguish between 'religious duty', which is clearly an integral part of religious obligation and is non-disputable among loyalists of religious institutions (for instance, eating pork among Jews); and 'religious preference', which includes disputable behaviors that are not common to all members of the religious group. ${ }^{33}$ There are two types of identity greediness of individuals towards the public space:

1. Personal identity greediness-are norms that are expressed towards the public space and directly impact the individual's identity and ability to express it in its ideal form. ${ }^{34}$ For instance, religious soldiers refusing to hear women's singing in the IDF's space.

2. Space forming identity greediness-attempts to form the space according to its given identity perception, even when the space does not undermine the realization of the individual's identity. ${ }^{35}$ An example of this are confrontations over the visibility of the public sphere in Israel on a range of issue such as commerce on the Sabbath (Yahud and Finkelstain 2016), Kosher food, Jewish burial and more (Ben-Porat 2013). ${ }^{36}$

A high level of identity greediness of both types would be expressed in a desire to express one's identity in public spaces even when this may result in confrontation. A low level of identity demandingness would be expressed in integration or assimilation in the space, and low demands, if any, to change its character.

From this we can derive a range of possibilities and categories on a continuum between two possible extremes of identity encounters in public spaces (Figure 1):

30 In this context, it is worthwhile to mention the term Multi Faith Spaces (MFSs) - such as common prayers areas for different religions (Biddington 2013) and neutral cemeteries (Bobrowicz 2018) as a solution for the question of the daily practice of using the public spaces. In a broader sense, the term pertains to integrated neighborhoods that include individuals practicing different religions, as well as non-religious individuals (Prideaux 2019).

31 The choice of separate identity groups such as ultra-orthodox Jews in Israel to create homogenous 'sphericules' for their daily use shows that they perceive contact with other groups as threatening to their identity.

32 At the same time, the terms and the model may also be implemented to non-religious identities such as ethnic identities, national, feminist, or LGTB (for further information see Umiel-Feldman 2016).

33 In this context is should be noted that seemingly objective measures distinguishing between duty and preference are problematic, as it is difficult to ascribe identity rules from the outside, to persons holding a given identity. There are Muslim women who wear a hijab or Burqa because it is a religious law (Medina 2014: 880-82) even if other Muslim women would describe it as a preference (Hass and Lutek 2019, pp. 6-7).

34 An interesting example of such identity greediness in the compulsory IDF space is the integration of the Black Hebrews of Dimona in the IDF, despite the fact that their identity practices demand special dietary needs, uniforms made of a different cloths than the IDF uniform, and more (Esensten 2019).

35 According to Haynes (1998), religion refuses to come to terms with its designated role in the private sphere.

36 Our case study of women's singing has also included space forming demands such as the avoidance of forming mixed gender combat units. However, such demands are outside the scope of the current discussion. 


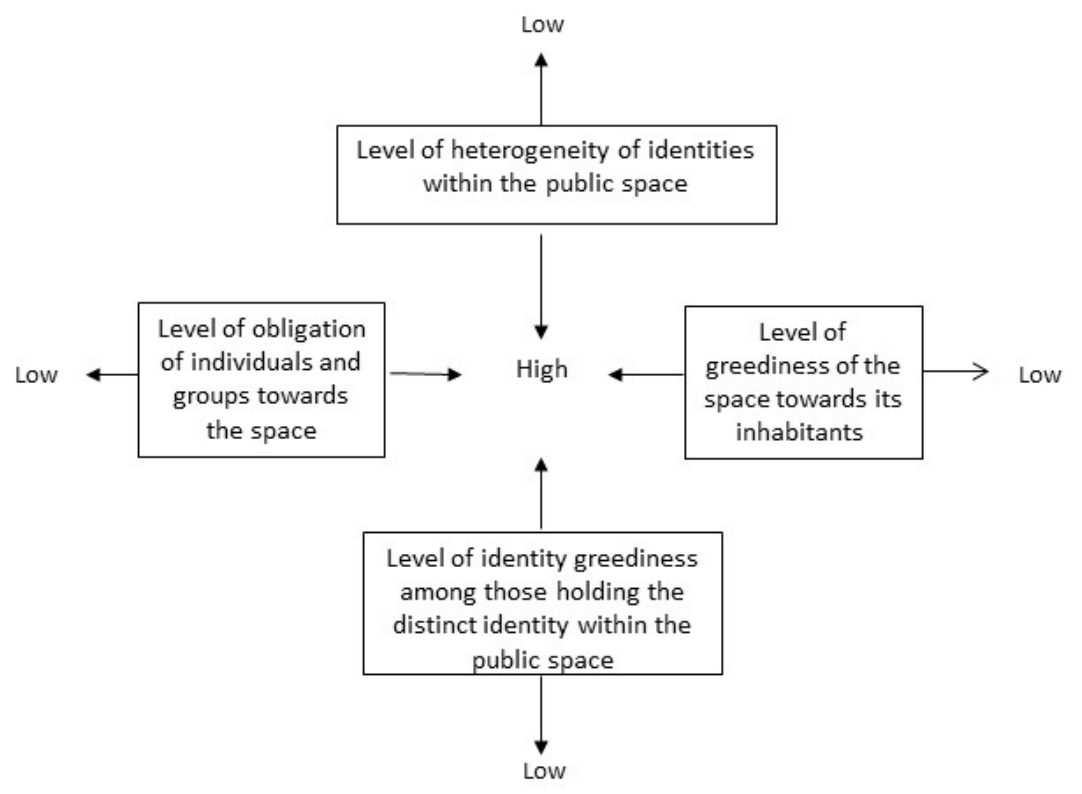

Figure 1. The Confrontation Model.

The intense confrontation extreme ${ }^{37}$ - which is the focus of the current paper and the center of the model, where there are high levels of all four dimensions: A high level of obligation (legal, essential, or symbolic) of individuals or groups to be in the public space; the space is greedy in terms of identity and also practically towards its individuals; the space is heterogenic and contains at least two opposing identities; and the individuals towards the space have high identity greediness towards forming the space in a way suited to their identity.

The legally binding IDF space represents a space characterized by the highest potential for confrontation, as the duty to be in it is legally enforced on all individuals reaching the age of eighteen ${ }^{38}$, a fact that results in its high level of heterogeneity; its high level of practical and identity greediness compared to all other public spaces, and necessarily also the presence of individuals and groups having a high level of identity greediness. It is no wonder, then, that an ongoing, persistent, and potent struggle has taken place within it on the question of women's singing and other related issues, extending to wider struggles in other public spaces in Israel.

In the cases of confrontations on women's singing in the IDF, the four dimensions were high: Individuals having a high level of Haredi-Leumi / Torani greediness ${ }^{39}$, serving beyond the basic legal greediness of the IDF service-in an officer's course naturally characterized within the IDF by very high practical and identity greediness; and the space is heterogenic and includes individuals with diverse and often opposing identities.

Therefore, due to high levels of all four dimensions of the model, not only was a confrontation imminent, but its level, scope, and duration were substantial and even permeated the Israeli public discourse in the wider context of the exclusion of women. Moreover, the halachic prohibition trickled from the army to additional public spaces. ${ }^{40}$ In parallel, the issue continued to permeate public

37 High or low levels of confrontation are measured in the context of what is common and accepted in a certain society. High level confrontation may be expressed in physical confrontation in the public spaces themselves (such as in the case of the riots in France around the Burqa Ban) or confrontations taking place in the public sphere (in Habermas' terms) and their level would be compared to other confrontations in a given society: The duration of the confrontation, its scope and the extend of expressions of polarization derived from it.

38 With the exception of individuals and groups who are excluded from it by law.

39 Orthodox-nationalists are a social-religious group that is part of religious-Zionism having adopted stricter religious patterns, similarly to ultra-Orthodox groups.

40 Such as national memorial ceremonies and even song competition reality shows such as The Voice (see, for instance, Umiel-Feldman 2016, pp. 226-34, 271-78). 
awareness, which in turn strengthened the 'culture war' atmosphere and the mutual sense of threat between the different identities.

In this context we recall the voices heard in the religious-Zionist camp, calling religious soldiers not to enlist in the IDF-meaning not to be in a compulsory and greedy space which does not facilitate their separate religious identity to coexist in it. This discussion is especially important in view of the definition of the compulsory space as a trigger for confrontations between identities, and the heated public debate on compulsory military service for ultra-orthodox Jews. While a substantial part of the ultra-orthodox (Haredi) population does not enlist in the IDF, by virtue of the 'Torato Umanuto' arrangement ${ }^{41}$, the rest of the State's Jewish citizens, including religious-Zionists, are obligated by law to enlist. These voices explicitly signal an intense confrontation, and it is easy to assume what would happen in a scenario of growing rates of conscription of Haredim to the IDF, with their especially high greedy identity.

The other side of the continuum is non-confrontation-where individuals having low identity greediness are voluntarily present in homogenous public spaces that are low in its greediness. Under such circumstances, it is difficult to imagine a confrontation resulting from a conflict between the identity of the individual and that of the public space. However, lack of confrontation can also be seen when the three dimensions of the model: Obligation, greediness, and heterogeneity, are high, while individual greediness is low. For instance, in the case of the cadets from the officer's training course who left the venue in 2011 when women were singing, out of 93 religious cadets, only nine actually left the venue (Cohen and Susser 2014).

Between these two extremes is a wide range of categories in which some of the dimensions would be high and others low. The relationships between the dimensions affect the intensity of the potential confrontation (see Appendix A-Sixteen Categories emerging from the model).

\section{Between Confrontation, Decision and Accommodation}

In the midst of an initial round of confrontation taking place in a given space or spaces on the same topic, as the situation gets closer and closer to the confrontation side of the continuum, where all four dimensions are high, the feasibility of decisions being made in favor of the identity of the given space increases. The closer the case proceeds towards the opposing side of the continuum-where the strength, scope, and duration of the confrontation are less intense-the higher the feasibility that a decision would be made in favor of the identity of the distinct individual/group. The identity representatives of the hegemonic majority will express a low willingness, or outright opposition to comply with high identity greediness perceived as able to transform the character of the Public Space and therefore the decision in such case would tend to be against the demands of the distinct group. However, the closer we get to the opposite side without strong confrontation, the hegemonic identity is able to compromise and flex its positions as part of the need to integrate the range of identities existing within the Public Space without fear of changing the identity of the space itself. But as long as the confrontation continues, we see two phenomena taking place in parallel and changing the decision trends presented above:

(a) The Circular Model—Between Confrontation and Accommodation

41 The arrangement allows Yeshiva students to postpone their enlistment in the IDF, subject to studying the Tora for 45 weekly hours and not working, with due adjustments based on the candidate's age and number of children. In reality, many ultra-orthodox Jews do not enlist in the IDF at all, or do so only for a short four month service. According to amendment 21 to the Conscription Law, if by 2023 the target quota of ultra-orthodox soldiers is not filled, the 'Torato Umanuto' ("Torah study is their occupation") arrangement would be revoked and the deferment of their service would be at the discretion of the ministry of Defense based on the government's conscription targets (See Security Service Law, Amendment 21, 2015). This issue has been widely deliberated by all Israeli governments in the past decade, causing numerous coalition disputes and crises. 
The rounds of confrontation and Accommodation function in a circular mode (Figure 2). ${ }^{42}$ The same confrontations between greedy identities in the various Public Spaces are conducted in a recurring circular pattern in differing forms and methods. A confrontation results in accommodation, which in turn pacifies the confrontation until it erupts once again in different public spaces, often not where it started in the first place. Sometimes the confrontation takes on different forms, but deals with the same topic.

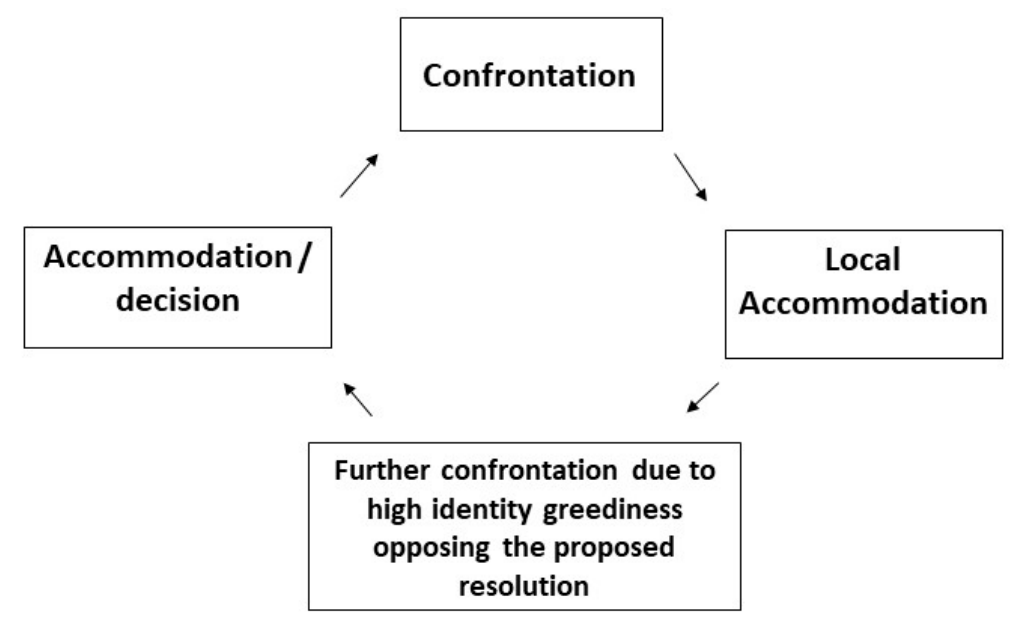

Figure 2. The Circular Model.

The model is circular because the demands for forming the space according to identity greediness, and all the more so when this greediness is at its highest, do not end. A resolution that contradicts the high demandingness identity causes dissatisfaction and a potential risk of an outbreak remains because of the nature of the accommodation.

The 2010 confrontation led to a resolution which was not accepted by the side characterized by high Zionist-religious greediness, nor by some of the decision makers within the IDF's secular command. From a religious-Zionist point of view, their dissatisfaction resulted from their understanding that the compromise relies on a weak and marginal interpretation of the Halacha, an interpretation that was perceived by them as contradicting their religious duty. Conversely, from the viewpoint of some of the secular decision makers in the IDF's command, it was essential to ensure total obedience and maintain the IDF's hegemonic identity, with awareness for the issue becoming more pronounced following the previous occurrence. This of course led to a second confrontation the following year, to which both sides arrived with more experience, set in their opinions, and fully situated in a culture war atmosphere.

Moreover it is clear that in certain matters, due to the distinction between different public spaces, accommodation and even decision in one public space does not always apply to other public spaces characterized by different levels of obligation and greediness, and the confrontation may spread onto them as was in fact the case in Israel: Women's singing has become an ongoing public debate in other public spaces as well. ${ }^{43}$

\section{(b) A Culture War Atmosphere}

Culture war is a term expressing a struggle which does not involve the use of physical violence per se, and takes place between social groups of differing and even opposing identities, ideologies, and values (Hunter 1991). The term has been continuously accompanying Israel society from its early

42 This is based on the concept of the politics of arrangement-by which mutual concessions and negotiations take place, and a compromise is reached until the next crisis that again changes the arrangement plan, and so forth (Don-Yehiya 1999).

43 See footnote number 44 . 
stages, especially in the context of religious-secular relations (Luz 1988; Ravitzky 1997). In a public atmosphere of culture war, there is growing risk of increasing the greediness levels of the different identity groups and of the representatives of the space expressing its identity. Our case studies on women's signing clearly express the culture war atmosphere in the public discourse, as they incite it and enhance confrontations on the definition of the public spaces. Although it is not a dimension in the model, it is nonetheless an important concept in the model's implementation on different case studies. It is an external social factor that highly influences the measures of identity greediness of the space and those in it, and therefore also of the level of confrontation and tendency for accommodation or decision in favor of one of the identities taking part in the confrontation within the public space.

As we have seen in the context of the IDF confrontation on the high confrontation axis, accommodation and decision tended in the end towards the identity of the public space, while later recurring circles of accommodation and confrontation were expressed in a culture war atmosphere. Such recurring events result in resolution attempts that tend, in certain cases, in favor of the identity greediness of the distinct group despite public demands to once again impose the accepted values of the public space on current and future occurrences. In the following section we illustrate this briefly, using the example of the religious demand of Muslim women to cover their heads or faces in public spaces due to their religious practices.

\section{Identity Struggles in French Public Spaces-The Burqa Ban}

In 2015, the matter reached the European Court of Justice after the employment contract of Ebrahimian, a worker in a public hospital in France, which is an essential public space, was not renewed because she wears a traditional Muslim head cover. The court ruled in favor of the identity of the public space (Brems 2015). However, the struggle was rekindled with the attempt to ban women from wearing 'burkinis' - bathing suits covering the head and entire body, on French beaches. In this case France's Supreme Court ruled that the ban would be cancelled, at least within the city of Nice (Dearden 2016). Clearly this voluntary space has a strong public resonance and the demand to ban women from wearing burkinis is a result of a culture war atmosphere which increases the level of identity greediness in all public spaces, including the voluntary ones normally characterized by lower levels of greediness.

As long as the four dimensions of the model are high — the identity greediness of the public space (identity of the majority) would prevail, as occurred in the Ebrahimian ruling in France: It is an essential public space (pertaining to the group of obligatory spaces), greedy by nature for those staying and working it in, heterogenic and having a high level of identity greediness (the identity greediness of the appellant who wished to use a head cover were high). We will now present the universal quality of the model through a short review of the ways in which armies around the world dealt with the issue of Muslim head cover. Religious head cover and uniform—compulsory spaces around the world.

Many armies around the world do not rely on compulsory enlistment, or conscription. To attract sufficient candidates and increase conscription rates, armies need to provide a space that would not challenge distinct identities. In a military space where conscription is non-mandatory, candidates can simply choose not to take part in a space that limits and challenges their identity.

In the global era, countries and societies around the world are coping with the need to integrate populations of immigrants and ethnic minorities. The Burqa Ban which swept through Europe in the past decade, clearly points to the existence of hegemonic public spaces coping with identity demands to change their nature. ${ }^{44}$

44 There is a difference between the ban on facial covering in many European countries such as France, Holland, Denmark, and others, which relies mainly on security and safety arguments, and the ban on wearing religious characteristics such as the hijab-a head cover that does not cover the entire face-which exists mainly in France, with similar controversies taking place in other countries as well, especially in the context of essential and obligatory public spaces. 
In case of a religious edict to cover women's heads as part of the daily practices or Muslim women in Western States, it is certainly possible that this demand would reach military institutions of varying levels of obligation and greediness.

As noted, the level of obligation to be in the public space regulates the level of identity demands made towards it. In a country enforcing compulsory military service for all its citizens, the army is required to deliberate on questions of identity to a much wider extent than voluntary armies, because of the obligation to recruit heterogenic identity groups characterized by differing levels of identity greediness.

A soldier wearing a 'yarmulke' (skull cap) is a common sight in the IDF. ${ }^{45}$ The Norwegian army also permits its soldiers to wear religious head covers such as a skull cap, turban, or hijab.

However, as stated before, the culture war atmosphere in the background of confrontations between identities in public spaces increases the feasibility of a resolution leaning towards the hegemonic identity of the national public sphere. ${ }^{46}$ Lillevik's (2019) comparison of two similar cases which occurred in two armed forces organizations in Norway, reinforces this argument. The Norwegian army is a legally binding public space, as men (and women as of 2015) are obligated to serve in it. Already in 1989, the army allowed Sikh soldiers to wear a turban in addition to the military uniform, and in 2013, with the rise in the number of Muslim women serving in the army, an explicit order was issued to allow wearing a hijab. However, in 2008, when a young woman of Algerian descent wished to study in Norway's Police Academy wearing a hijab, she was told that the matter had been discussed in the past and denied. The case caused a public uproar that concurred with the culture war atmosphere prevalent throughout Europe during that time on allowing hijabs to be worn in European public spaces. Clearly the public atmosphere in Europe in 1989 as to the public visibility of ethnic minorities was nothing like the atmosphere in the mid 2010's, among other reasons also due to the significant rise in the number of immigrants living in Europe.

Armies that are not compulsory spaces, but nevertheless are required to cope with the need to attract recruits with demanding characteristics, understand the need to create a space that is clear of identity conflicts. In Australia ${ }^{47}$, Canada ${ }^{48}$, and the $\mathrm{UK}^{49}$ we see female soldiers wearing hijab during their services, and even the USA (Mayers 2017) joined the list of countries that permit external religious characteristics such as the hijab, or the turban for Sikhs, or beards grown for religious reasons.

In Germany, on the other hand, despite the understanding that the diverse religious groups within the army should be catered to, and a specialized unit that was established to handle the matter, religious head covers including yarmulkes, turbans, and hijabs are still prohibited ${ }^{50}$. In July 2016, it was reported in France that the French Minister of Internal Affairs requested that citizens volunteer for reserve military service in order to protect the State following a terror attack in Nice that month. However, two French Muslim sisters of Moroccan descent who wished to volunteer to help were requested to remove their hijab to be permitted entry into the recruitment center. One of them refused

45 Also, a review of the IDF's official rules of appearance and dress code shows that religious women serving in the IDF are permitted to cover their heads: https://www.mitgaisim.idf.il/\%D7\%9B\%D7\%AA\%D7\%91\%D7\%95\%D7\%AA/english/rightsand-obligations/the-military-rules-of-appearance-and-dress-code/\#/.

46 This is true even if the nature of the event is clearly characteristic of the distinct culture. The general atmosphere of threat to the hegemonic identity results in attempts to change the nature of events pertaining to distinct identity groups. In Israel, gender separation events intended for the religious and ultra-religious populations have been cancelled due to public opposition to gender separation (see, for instance: Lior 2019) and in some cases the dilemma reached the Supreme Court (Shpigel 2019).

47 Australian Defense Forces-Army Dress Manual, Chapter 3: Items of dress, embellishments \& accoutrements: https://www.army.gov.au/sites/default/files/army_dress_manual_201712_chapt_3_items_of_dress_embellishments_and_ accoutrements.pdf?acsf_files_redirect.

48 Canadian armed forces-Dress instructions, Section 3-Religious and spiritual accommodation: https://www.canada.ca/en/ services/defence/caf/military-identity-system/dress-manual/chapter-2/section-3.html\#3-1.

49 The British Army—Faiths in the army: https://apply.army.mod.uk/what-we-offer/what-we-stand-for/faith.

50 The German Army: https://www.bundeswehr.de/de/organisation/weitere-bmvg-dienststellen/zentrum-innere-fuehrung/dasein-fuer-soldatinnen-und-soldaten-aller-glaubensrichtungen--100550. 
and left the premises, while the other agreed to remove her hijab and even returned a week later and again was asked to remove her hijab to enter (Estrin 2016). Such cases, even if not involving full military conscription, point to the confrontation potential of encounters between differing identities in public spaces, especially compulsory ones involving high levels of greediness. Meanwhile, various European countries are reinstating compulsory military service. ${ }^{51}$

In 2018, it was published that France intends to reinstate compulsory military service, due to a national aim to strengthen citizens' sense of duty, national unity, and social cohesion. President Macron's plan includes a one-month obligatory national service for 16-year-old boys and girls in the country (Williamson 2018).

The link between a heterogenic population that also includes distinct identities characterized by a high level of identity greediness and the establishment of legally binding public spaces is highly explosive. The model presented in this paper (Figure 1) clearly warns from the feasibility of intense confrontations when all four dimensions are high: The obligation to be in the Public Space; high level of practical and identity greediness of the space; heterogeneity within the Public Space; and a high level of identity obedience among persons and groups towards the Public Space. All these can be seen in the case of compulsory military service in European countries who have undergone a substantial demographic change in the past decades as a result of the waves of immigration into Europe. The French ban on head covers in 2010 resulted in a public outburst and ongoing violent demonstrations (cbs/ap. 2013). France, that prides itself in the secular identity greediness of its national public sphere, meanwhile is engrossed in efforts to reinstate compulsory military service. In such a state of split social identity, compulsory military service seems to be an excellent solution for softening the differences and creating a meeting point between identities. However, if we examine the four dimensions of the model, we will see that in fact the French situation is a recipe for intense confrontation, as the identity greediness of the public space are high as well. In addition, the case of a greedy and legally compulsory military space creates a public space that is perceived as belonging to all populations serving in it. Since not only do the struggles within it take place at a high level of intensity, also the accepted norms within it trickle down to similar struggles taking place in other public spaces in the country. This situation of reinstating compulsory military service in parallel to a clear policy against religious characteristics would most certainly result in an intense confrontation. The legally binding component in itself empowers the confrontation.

While France, Germany, and other European countries are still far from imposing compulsory military service on all their citizens, men and women alike, it is certainly worthwhile to consider a situation in which it would be obligatory to be in a greedy and heterogenic space, even if only theoretically. Compulsory military service in France would make it very difficult for the State to continue holding on to the complete ban on wearing religious characteristics in a legally binding space, including head cover for Muslim women, without paying the price of intensive civil and social confrontations, and even civil rebellion.

In a reality in which compulsory military service is imposed, the ban on religious characteristics is raised, and pictures of French female soldiers wearing hijabs are displayed on front pages-secular France would have a difficult time arguing in favor of the need for similar bans in other public spaces. The trickling of norms and social changes from the compulsory space to other public spaces in the country is inevitable in a democratic society in which a legally binding military space is present.

\section{Conclusions}

In this study, we presented a new theoretical conceptualization, which expands on existing conceptualizations in the field of public spaces, by relying on four dimensions to determine the type of

51 Lithuania did so in 2015 (Palowski 2015) and Sweden in 2017 (Reuters 2017), with similar ideas also being voiced in Germany (Janjevic 2018). 
public space: The extent in which being in the Public Space is compulsory (on a continuum between a legally binding public space and a voluntary one); the level of greediness of the public space towards its participants; the level of heterogeneity of identities within the public space; and the level of greediness of the identities towards the public space. In this context, the higher the obligation to be in the space, and the more it is greedy towards its participants, the higher the heterogeneity of the range of identities in the space and the higher identity greediness of the groups towards the public space- - the higher the potential for intense confrontation.

The conceptualization of the IDF as a legally binding public space enables a wider perception of its function, nature, and management in terms of the practices derived from the use of the space. Such conceptualization introduces a new theoretical framework, which in the future could apply to additional armies in democratic countries where obligatory service exists or will be introduced in future. The conscription component creates a huge challenge for this type of military institution, consisting of the need to balance between allowing individuals to serve under conditions, which will not cause them an identity conflict, while ensuring that the identity of the space itself would not be completely lost.

This model can be implemented, with slight adjustments, not only to additional armies around the world, but also to encounters between different identities in further public spaces in different countries, being fertile ground for public struggles in many areas such as the struggles taking place in Europe between the hegemonic western identity and the identities of immigrants over public visibility in the various public spaces, or struggles involving gay pride parades around the world.

This new conceptualization sheds light also on armies which are not legally binding public spaces, but are nevertheless greedy and heterogenic by nature, and that wish to attract and recruit as many candidates as possible. To do this, they must create a heterogenic space in which diverse identities may coexist without challenging individuals of distinct identities.

Using the four dimensions of this model of identity encounters in public spaces, we are able to estimate the intensity of an identity struggle over the nature of different public spaces, its duration and scope, and to explain decisions and resolutions reached following confrontations.

The conceptualization of public spaces and mapping of potential confrontations between identities coexisting within them on a continuum or range of possibilities, are important for understanding processes taking place not only in Israel, and not only in the military space, but also in other parts of the world and in additional types of public spaces.

Funding: This research received no external funding.

Acknowledgments: I would like to thank my colleagues Asher Cohen and Sharon Haleva Amir for their valuable comments; and to the anonymous reviewer whose comments have greatly improved this manuscript.

Conflicts of Interest: The author declares no conflict of interest.

\section{Appendix A. 16 Categories Emerging from the Model}

The four indices of the model 'Identity encounters in Public Spaces': (a) The level of obligation to be in the Space; (b) the level of greediness of the public space; (c) the level of heterogeneity of identities among individuals in the public space; and (d) identity greediness of the individuals towards the public space, create 16 categories distinguishable in the level of each index (high/low).

The variety of options range between the pole where all the indices are at a high level (Category 1 , on which this paper was focused), and the opposite pole where all indices are at their lower level (Category 2). 
Table A1. High potential confrontation.

\begin{tabular}{|c|c|c|c|}
\hline Indices & High & Low & Example \\
\hline level of obligation to be in the space & + & & \multirow{3}{*}{$\begin{array}{l}\text { Continuous identity struggles over the nature of the } \\
\text { IDF space, for instance-the matter of women's } \\
\text { singing in the IDF on which this paper focused, and } \\
\text { other struggles such as the dispute regarding joint } \\
\text { military service for men and women; struggles over } \\
\text { the past decade within the IDF between the Education } \\
\text { corps and the Military }\end{array}$} \\
\hline $\begin{array}{l}\text { level of greediness of the } \\
\text { public space }\end{array}$ & + & & \\
\hline $\begin{array}{l}\text { level of heterogeneity of identities } \\
\text { among individuals in the } \\
\text { public space }\end{array}$ & + & & \\
\hline $\begin{array}{l}\text { Identity greediness of the } \\
\text { individuals towards the } \\
\text { public space }\end{array}$ & + & & $\begin{array}{l}\text { Rabbinate; and the religionization discourse which } \\
\text { began in } 2010 \text { on the empowerment of religious factors } \\
\text { and their influence on the IDF. }\end{array}$ \\
\hline
\end{tabular}

Table A2. Low potential confrontation.

\begin{tabular}{lccc}
\hline \multicolumn{1}{c}{ Indices } & High & Low & Example \\
\cline { 1 - 2 } level of obligation to be in the space & + & \\
\cline { 1 - 2 } level of greediness of the public space & + & $\begin{array}{l}\text { An extended family event in a private room in a } \\
\text { restaurant or at a park in a homogenous population. }\end{array}$ \\
$\begin{array}{llll}\text { level of heterogeneity of identities } \\
\text { among individuals in the public space }\end{array}$ & + & +
\end{tabular}

Table A3. Medium potential confrontation.

\begin{tabular}{|c|c|c|c|}
\hline Indices & High & Low & Example \\
\hline level of obligation to be in the space & + & & \multirow{4}{*}{$\begin{array}{l}\text { The IDF, until the early 2000s, did not encounter } \\
\text { significant identity claims that demanded to reshape } \\
\text { its character after basic claims had already been settled. }\end{array}$} \\
\hline level of greediness of the public space & + & & \\
\hline $\begin{array}{l}\text { level of heterogeneity of identities } \\
\text { among individuals in the public space }\end{array}$ & + & & \\
\hline $\begin{array}{l}\text { Identity greediness of the individuals } \\
\text { towards the public space }\end{array}$ & & + & \\
\hline
\end{tabular}

Table A4. Low potential confrontation.

\begin{tabular}{|c|c|c|c|}
\hline Indices & High & Low & Example \\
\hline level of obligation to be in the space & + & & \multirow{4}{*}{$\begin{array}{l}\text { A democratic school where the level of obligation to be } \\
\text { in the space is compulsory according to the } \\
\text { compulsory education Law, but the space's character } \\
\text { as democratic results in a low level of the other indices. }\end{array}$} \\
\hline level of greediness of the public space & & + & \\
\hline $\begin{array}{l}\text { level of heterogeneity of identities } \\
\text { among individuals in the public space }\end{array}$ & & + & \\
\hline $\begin{array}{l}\text { Identity greediness of the individuals } \\
\text { towards the public space }\end{array}$ & & + & \\
\hline
\end{tabular}

Table A5. Low potential confrontation.

\begin{tabular}{|c|c|c|c|}
\hline Indices & High & Low & Example \\
\hline level of obligation to be in the space & & + & \multirow{4}{*}{$\begin{array}{l}\text { An ideological youth movement is a voluntary space } \\
\text { characterized by high levels of identity greediness and low } \\
\text { levels of heterogeneity. Thus, in most cases, the individuals } \\
\text { within it have no identity demands towards the space, as they } \\
\text { enter it of their free will because it corresponds with their own } \\
\text { ideology and identity, both in terms of the space itself and of } \\
\text { its heterogeneity (specific examples include the 'Ezra' youth } \\
\text { movement, 'Hashomer Hatzair', etc.). }\end{array}$} \\
\hline level of greediness of the public space & + & & \\
\hline $\begin{array}{l}\text { level of heterogeneity of identities } \\
\text { among individuals in the public space }\end{array}$ & & + & \\
\hline $\begin{array}{l}\text { Identity greediness of the individuals } \\
\text { towards the public space }\end{array}$ & & + & \\
\hline
\end{tabular}


Table A6. Low potential confrontation.

\begin{tabular}{|c|c|c|c|}
\hline Indices & High & Low & Example \\
\hline level of obligation to be in the space & & + & \multirow{4}{*}{$\begin{array}{l}\text { A reality show such as 'Kohav Nolad' ('A Star is Born', the Israeli } \\
\text { equivalent of 'American Idol'). No demands were made for } \\
\text { participation without hearing women's singing (in contrast to the } \\
\text { 'The Voice' program, which did include such a demand (see, for } \\
\text { example: Stern 2018; Gronich 2014). It is a voluntary, non-greedy } \\
\text { space in its character (compared to other reality shows such as 'Big } \\
\text { Brother', which is a space that is high on greediness), heterogeneous } \\
\text { in terms of participants, and no identical demands from the } \\
\text { individuals participating to shape the space according to their } \\
\text { identity were observed. }\end{array}$} \\
\hline $\begin{array}{l}\text { level of greediness of the } \\
\text { public space }\end{array}$ & & + & \\
\hline $\begin{array}{l}\text { level of heterogeneity of identities } \\
\text { among individuals in the } \\
\text { public space }\end{array}$ & + & & \\
\hline $\begin{array}{l}\text { Identity greediness of the } \\
\text { individuals towards the } \\
\text { public space }\end{array}$ & & + & \\
\hline
\end{tabular}

Table A7. Low potential confrontation.

\begin{tabular}{|c|c|c|c|}
\hline Indices & High & Low & Example \\
\hline $\begin{array}{l}\text { level of obligation to be in } \\
\text { the space }\end{array}$ & & + & \multirow{4}{*}{$\begin{array}{l}\text { Events organized by secular municipalities designated for the religious and } \\
\text { ultra-Orthodox public, which take place under gender segregation } \\
\text { conditions: The conflict over whether there will be gender segregation in a } \\
\text { show for religious and ultra-Orthodox population in Afula in the summer of } \\
\text { 2019. It is a voluntary and non-greedy space (a city park), and the show is } \\
\text { aimed at a relatively homogeneous population with high levels of identity } \\
\text { greediness towards gender segregation during the show. This case occurred } \\
\text { in the broad context of a conflictual public discourse regarding gender } \\
\text { segregation in various spaces in Israel, and therefore it took the form of a } \\
\text { cultural war atmosphere. These terms explain the confrontation that took } \\
\text { place in this case, although this category is located at the low level of } \\
\text { confrontation (see, for example, Begno and Arik 2019). } \\
\text { A similar case demonstrating lower levels of confrontation was an event for } \\
\text { the religious public from the city of Holon at the Tel-Aviv Amusement Park, } \\
\text { where boys and girls were requested to queue in separate lines. }\end{array}$} \\
\hline $\begin{array}{l}\text { level of greediness of the } \\
\text { public space }\end{array}$ & & + & \\
\hline $\begin{array}{l}\text { level of heterogeneity of } \\
\text { identities among individuals } \\
\text { in the public space }\end{array}$ & & + & \\
\hline $\begin{array}{l}\text { Identity greediness of the } \\
\text { individuals towards the } \\
\text { public space }\end{array}$ & + & & \\
\hline
\end{tabular}

Table A8. Medium potential confrontation.

\begin{tabular}{|c|c|c|c|}
\hline Indices & High & Low & Example \\
\hline $\begin{array}{l}\text { level of obligation to be in } \\
\text { the space }\end{array}$ & & + & \multirow{4}{*}{$\begin{array}{l}\text { 'Lamed Heh' memorial march 2010: } \\
\text { In 2010, a gathering of various Israeli youth movements was held for a joint } \\
\text { memorial activity. This was a voluntary space (youth movements); with high } \\
\text { spatial identity greediness since youth movements are based on ideological } \\
\text { and identity affiliation; and the level of heterogeneity of the encounter was } \\
\text { high (as it included several different youth movements). Finally, the demand } \\
\text { of the religious Bnei Akiva movement not to hear women singing during the } \\
\text { ceremony expressed a high identity greediness of the religious identity of } \\
\text { that movement (Nahshoni 2010). }\end{array}$} \\
\hline $\begin{array}{l}\text { level of greediness of the } \\
\text { public space }\end{array}$ & + & & \\
\hline $\begin{array}{l}\text { level of heterogeneity of } \\
\text { identities among individuals } \\
\text { in the public space }\end{array}$ & + & & \\
\hline $\begin{array}{l}\text { Identity greediness of the } \\
\text { individuals towards the } \\
\text { public space }\end{array}$ & + & & \\
\hline
\end{tabular}

Table A9. Medium potential confrontation.

\begin{tabular}{|c|c|c|c|}
\hline Indices & High & Low & Example \\
\hline level of obligation to be in the space & + & & \multirow{4}{*}{$\begin{array}{l}\text { HMO clinics-are a necessary space (belonging to } \\
\text { the binding spaces group), as well as heterogeneous, } \\
\text { with low levels of greediness. } \\
\text { However, there are struggles regarding gender } \\
\text { segregation within clinics in cities such as Beit } \\
\text { Shemesh and Jerusalem (Linder and Even 2013). }\end{array}$} \\
\hline level of greediness of the public space & & + & \\
\hline $\begin{array}{l}\text { level of heterogeneity of identities } \\
\text { among individuals in the public space }\end{array}$ & + & & \\
\hline $\begin{array}{l}\text { Identity greediness of the individuals } \\
\text { towards the public space }\end{array}$ & + & & \\
\hline
\end{tabular}


Table A10. Medium potential confrontation.

\begin{tabular}{|c|c|c|c|}
\hline Indices & High & Low & Example \\
\hline $\begin{array}{l}\text { level of obligation to be in } \\
\text { the space }\end{array}$ & + & & \multirow{4}{*}{$\begin{array}{l}\text { The Religious Public Education 'sphericule' in Israel: } \\
\text { Due to Israel's compulsory education law, the education } \\
\text { system is a binding space as well as greedy (both practically } \\
\text { and identically). } \\
\text { A single cultural group in a space is referred to as 'sphericule': } \\
\text { A space characterized by relatively low levels of heterogeneity. } \\
\text { Even if it contains different identity streams, it is more } \\
\text { homogeneous than other subspaces. }\end{array}$} \\
\hline $\begin{array}{l}\text { level of greediness of the } \\
\text { public space }\end{array}$ & + & & \\
\hline $\begin{array}{l}\text { level of heterogeneity of } \\
\text { identities among individuals } \\
\text { in the public space }\end{array}$ & & + & \\
\hline $\begin{array}{l}\text { Identity greediness of the } \\
\text { individuals towards the } \\
\text { public space }\end{array}$ & + & & \\
\hline
\end{tabular}

Table A11. Low potential confrontation.

\begin{tabular}{|c|c|c|c|}
\hline Indices & High & Low & Example \\
\hline level of obligation to be in the space & + & & \multirow{4}{*}{$\begin{array}{l}\text { Schools with a homogeneous population such as } \\
\text { ultra-Orthodox schools; homogenous military } \\
\text { regiments in which the identity demands had already } \\
\text { been accepted (such as the sikh regiment in India). }\end{array}$} \\
\hline level of greediness of the public space & + & & \\
\hline $\begin{array}{l}\text { level of heterogeneity of identities } \\
\text { among individuals in the public space }\end{array}$ & & + & \\
\hline $\begin{array}{l}\text { Identity greediness of the individuals } \\
\text { towards the public space }\end{array}$ & & + & \\
\hline
\end{tabular}

Table A12. Low potential confrontation.

\begin{tabular}{|c|c|c|c|}
\hline Indices & High & Low & Example \\
\hline level of obligation to be in the space & + & & \multirow{4}{*}{$\begin{array}{l}\text { HMO Clinic in a city with no major ultra-orthodox } \\
\text { population. } \\
\text { A heterogeneous necessary space, non-greedy in its } \\
\text { character and without special identity demands from } \\
\text { the individuals in its domain. }\end{array}$} \\
\hline level of greediness of the public space & & + & \\
\hline $\begin{array}{l}\text { level of heterogeneity of identities } \\
\text { among individuals in the public space }\end{array}$ & + & & \\
\hline $\begin{array}{l}\text { Identity greediness of the individuals } \\
\text { towards the public space }\end{array}$ & & + & \\
\hline
\end{tabular}

Table A13. Medium potential confrontation.

\begin{tabular}{|c|c|c|c|}
\hline Indices & High & Low & Example \\
\hline level of obligation to be in the space & & + & \multirow{4}{*}{$\begin{array}{l}\text { Non-compulsory army: } \\
\text { Individuals with high levels of identity greediness } \\
\text { refrain from enlisting in its corps. } \\
\text { For example, the US Army is an AVF (All Voluntary } \\
\text { Force) Army, and ultra-Orthodox Jews hardly enlist } \\
\text { in its corps. }\end{array}$} \\
\hline level of greediness of the public space & + & & \\
\hline $\begin{array}{l}\text { level of heterogeneity of identities } \\
\text { among individuals in the public space }\end{array}$ & + & & \\
\hline $\begin{array}{l}\text { Identity greediness of the individuals } \\
\text { towards the public space }\end{array}$ & & + & \\
\hline
\end{tabular}


Table A14. Low potential confrontation.

\begin{tabular}{|c|c|c|c|}
\hline Indices & High & Low & Example \\
\hline level of obligation to be in the space & & + & \multirow{4}{*}{$\begin{array}{l}\text { Ideological conferences, for example for vegans. - } \\
\text { It is a voluntary space with a low level of } \\
\text { heterogeneity, high level of identity greediness (no } \\
\text { leather clothing, vegan food, etc.) and the vegan } \\
\text { identity demands of the individuals towards the } \\
\text { space are high (for more about vegan identity see: } \\
\text { Greenebaum 2012). }\end{array}$} \\
\hline level of greediness of the public space & + & & \\
\hline $\begin{array}{l}\text { level of heterogeneity of identities } \\
\text { among individuals in the public space }\end{array}$ & & + & \\
\hline $\begin{array}{l}\text { Identity greediness of the individuals } \\
\text { towards the public space }\end{array}$ & + & & \\
\hline
\end{tabular}

Table A15. Medium potential confrontation.

\begin{tabular}{|c|c|c|c|}
\hline Indices & High & Low & Example \\
\hline level of obligation to be in the space & & + & \multirow{4}{*}{$\begin{array}{l}\text { The struggle for allowing ritual immersion in Israel's } \\
\text { natural springs. - } \\
\text { A non-binding, non-greedy, heterogeneous space in } \\
\text { which individuals with high greediness of identity } \\
\text { seek to create a space free of women (Hasson 2018). } \\
\text { A similar conflict involves gender based separate } \\
\text { bathing beaches and hours in gyms and urban } \\
\text { swimming pools. }\end{array}$} \\
\hline level of greediness of the public space & & + & \\
\hline $\begin{array}{l}\text { level of heterogeneity of identities } \\
\text { among individuals in the public space }\end{array}$ & + & & \\
\hline $\begin{array}{l}\text { Identity greediness of the individuals } \\
\text { towards the public space }\end{array}$ & + & & \\
\hline
\end{tabular}

Table A16. Medium potential confrontation.

\begin{tabular}{|c|c|c|c|}
\hline Indices & High & Low & Example \\
\hline level of obligation to be in the space & + & & \multirow{4}{*}{$\begin{array}{l}\text { 'Mehadrin' segregated bus lines departing from ultra-Orthodox } \\
\text { neighborhoods, which also pass in non-Haredi areas - } \\
\text { This is a necessary space (public transportation) in which the } \\
\text { individuals hold a high level of identity greediness. } \\
\text { The greediness of the space in itself is not high, as this is a bus line } \\
\text { that not only goes through ultra-Orthodox neighborhoods, but is } \\
\text { aimed for the general population. However, heterogeneity in its } \\
\text { domain is not very high, as a majority of the passengers using this } \\
\text { line are ultra-Orthodox (see } \\
\text { Karmi and Shapira-Rosenberg 2012). }\end{array}$} \\
\hline level of greediness of the public space & & + & \\
\hline $\begin{array}{l}\text { level of heterogeneity of identities } \\
\text { among individuals in the public space }\end{array}$ & & + & \\
\hline $\begin{array}{l}\text { Identity greediness of the individuals } \\
\text { towards the public space }\end{array}$ & + & & \\
\hline
\end{tabular}

\section{References}

Alexander, Jeffrey C. 1988. The New Theoretical Movement. In Handbook of Sociology. Edited by Neil J. Smelser. Beverly Hills: Sage Publications, pp. 77-101.

Attali, Amichai. 2011. Cadets in Danger of Impeachment: Refused to Listen to a Female Singer. Nrg. Available online: http://www.nrg.co.il/online/1/ART2/281/545.html (accessed on 22 January 2020).

Begno, Yuval, and Bender Arik. 2019. Supreme Court Overruled Gender Segregation at Afula Event. Ultra-Orthodox: 'An Anti-democratic Decision'. Maariv. Available online: https:/www.maariv.co.il/ news/israel/Article-712721 (accessed on 5 March 2020). (In Hebrew).

Benhabib, Seyla. 1992. Situating the Self: Gender, Community and Postmodernism in Contemporary Ethics. Cambridge: Polity Press.

Benhorin, Yitzhak. 2011. Clinton: Worried about the Decline of Democracy in Israel. Ynet. Available online: http://www.ynet.co.il/articles/0,7340,L-4156547,00.html (accessed on 22 January 2020). (In Hebrew).

Ben-Porat, Guy. 2013. Between State and Synagogue, the Secularization of Contemporary Israel. Cambridge: Cambridge University press.

Berman, Sol. 1980. Kol Isha (Woman's Voice). In Joseph Lookstien Memorial Volume. New York: Ktav Publishing House Inc., pp. 45-66. Available online: http://www.edah.org/docs/Kol\%20Isha.pdf (accessed on 29 January 2020).

Bick, Ita. 2015. Mandatory Civil Service: Implications on Religious and Haredi Women. In Mandatory Service or the Duty to Serve? Scenario Analysis of Mandatory Civil Service in Israel. Edited by Yagil Levy. Raanana: Open University of Israel, pp. 95-120. Available online: http://din-online.info/pdf/op26.pdf (accessed on 19 February 2020). (In Hebrew) 
Biddington, Terry. 2013. Towards a Theological Reading of Multifaith Spaces. International Journal of Public Theology 7: 315-28. [CrossRef]

Bobrowicz, Ryszard. 2018. Multi-Faith Spaces Uncover Secular Premises Behind the Multi-Faith Paradigm. Religions 9: 37. [CrossRef]

Bourdieu, Pierre. 1977. Outline of a Theory of Practice. Translated by Richard Nice. Cambridge and New York: Cambridge University Press.

Breiner, Josh. 2010. Cadets Walked out on a Rabin Memorial Ceremony Due to Women's Singing and Were Incarcerated. Walla! News. Available online: http://news.walla.co.il/item/1745987 (accessed on 23 February 2016). (In Hebrew).

Brems, Eva. 2015. Ebrahimian V. France: Headscarf Ban Upheld for Entire Public Sector. Strasbourg Observer. Available online: https://strasbourgobservers.com/2015/11/27/ebrahimian-v-france-headscarf-ban-upheldfor-entire-public-sector/ (accessed on 29 January 2020).

Chiodelli, Francesco, and Stefano Moroni. 2014. Typology of spaces and topology of toleration: City, pluralism, ownership. Journal of Urban Affairs 36: 167-81. [CrossRef]

Claval, Paul, Maria Paola Pagnini, and Maurizio Scaini, eds. 2003. The Cultural Turn in Geography: Proceeding of the Conference, 18-20th of September 2003 Gorizia Campus. Trieste: University of Trieste, Available online: https://www.academia.edu/5944503/The_role_of_Literary_Parks_in_the_reappropriation_of_the_ cultural_identity_of_place.pdf (accessed on 9 January 2020).

Cohen, A. Stuart. 1997. The Scroll or the Sword? Dilemmas of Religion and Military Service in Israel. Amsterdam: Harwood Academic Publishers.

Cohen, A. Stuart. 2001. Dimensions of Tension between Religion and Military Service in Contemporary Israel. In Military, State and Society in Israel. Edited by Daniel Maman, Eyal Ben-Ari and Zeev Rosenhek. Piscataway: Transaction Books, pp. 176-78.

Cohen, Asher, and Bernard Susser. 2014. Women Singing, Cadets Leaving. In Civil-Military Relations in Israel. Edited by Elisheva Rosman-Stollman and Aharon Kampinsky. New York: Columbia University Press, pp. 127-45.

Cohen, Stuart, Aaron Kampinsky, and Elisheva Rosman-Stollman. 2016. Swimming against the tide: The changing functions and status of chaplains in the Israel Defense Force. Religion, State and Society 44: 65-74. [CrossRef]

Coser, Lewis Alfred. 1974. Greedy Institutions: Patterns of Undivided Commitment. New York: Free Press.

Dahlgren, Peter. 1993. Introduction. In Communication and Citizenship: Journalism and the Public Sphere in the Media. Edited by Petter Dahlgren and Colin Sparks. London: Routledge, pp. 1-24.

De Certeau, Michel. 1984. The Practice of Everyday Life. Oakland: University of California Press.

Dearden, Lizzie. 2016. Burkini Ban Suspended: French Court Declares Law Forbidding Swimwear Worn by Muslim Women 'Clearly Illegal'. Independent. Available online: https://www.independent.co.uk/news/world/europe/burkini-ban-french-france-court-suspends-rule-lawforbidding-swimwear-worn-muslim-women-seriously-a7211396.html (accessed on 8 January 2020).

Don-Yehiya, Eliezer. 1999. Religion and Political Accommodation in Israel. Jerusalem: The Floresheimer Institute.

Elden, Stuart. 2004. Understanding Henri Lefebvre. London: Continuum.

Esensten, Andrew. 2019. Yah's Exemplary Soldiers: African Hebrew Israelites in the Israel Defense Forces. Religions 10: 614. Available online: https://www.mdpi.com/2077-1444/10/11/614 (accessed on 27 January 2020). [CrossRef]

Estrin, Daniel. 2016. French Army Asks Citizens To Enlist—But No Muslim Headscarves, Please. Npr. Available online: https://www.npr.org/sections/parallels/2016/07/26/487468832/french-army-asks-citizens-to-enlistbut-no-muslim-headscarves-please (accessed on 21 January 2020).

Ettinger, Yair. 2011. Top Settler Rabbi: Soldiers Will Sooner Choose Death Than Suffer Women's Singing. Haarez. Available online: https://www.haaretz.com/1.5210733 (accessed on 22 January 2020).

Fraser, Nancy. 1990. Rethinking the Public Sphere: A Contribution to the Critique of Actually Existing Democracy. Social Text 25: 56-80. [CrossRef]

Gal, Susan. 2002. A semiotics of the public/private distinction. Differences: A Journal of Feminist Cultural Studies 13: 77-95. [CrossRef]

Gal, Reuven, and Tamir Libel, eds. 2012. Between the Yarmulke and the Beret: Religion, Politics and the Military in Israel. Modan: Ben-Shemen. (In Hebrew) 
Gavrilovic, Denijela, and Dragoljub B. Dordevic. 2018. Religionization of Public Space: Symbolic Struggles and Beyond-The Case of Ex-Yugoslav Societies. Religions 9: 36. Available online: https://www.mdpi.com/20771444/9/2/36 (accessed on 27 January 2020). [CrossRef]

Gitlin, Todd. 1998. Public sphere or public sphericules? In Media, Ritual and Identity. Edited by Tamar Liebes and James Curran. London: Routledge, pp. 168-74.

Greenebaum, Jessica. 2012. Veganism, Identity and the quest Authenticity. Food, Culture E Society 15: 129-44.

Gronich, Zvika. 2014. Due to Women's Singing: 'The Voice' Challenger-Eyal Cohen-Absent from Final's Stage. Kikar Hashabat. Available online: http://www.kikar.co.il/\%D7\%91\%D7\%92\%D7\%9C\%D7\%9C-\%D7\% A9\%D7\%99\%D7\%A8\%D7\%AA-\%D7\%A0\%D7\%A9\%D7\%99\%D7\%9D-\%D7\%9E\%D7\%AA\%D7\%9E\%D7\% 95\%D7\%93\%D7\%93-\%D7\%93\%D7\%94-\%D7\%95\%D7\%95\%D7\%99\%D7\%99\%D7\%A1-\%D7\%90\%D7\%99\% D7\%9C-\%D7\%9B\%D7\%94\%D7\%9F.html (accessed on 4 November 2015). (In Hebrew).

Haaretz. 2011. IDF Chief: Religious Soldiers Not Excused from Official Events Where Women Sing. Haaretz. Available online: https://www.haaretz.com/1.5222803 (accessed on 26 January 2020).

Habermas, Jurgen. 1989. The Transformation of the Public Sphere: An Inquiry into a Category of Bourgeois Society. Cambridge: MIT Press.

Habermas, Jurgen. 1991. The Structural Transformation of the Public Sphere. Cambridge: The MIT Press.

Hanafi, Rania. 2019. From One Islam to Another: A Paradoxical Agency of the Entry into Female Students' Careers. Religions 10: 176. Available online: https://www.mdpi.com/2077-1444/10/3/176 (accessed on 25 January 2020). [CrossRef]

Harel, Amos. 2011a. IDF General Causes Storm after Calling to Curtail Religiosity in Army. Haaretz. Available online: https://www.haaretz.com/1.5031135 (accessed on 22 January 2020).

Harel, Amos. 2011b. Bahad 1 [IDF Officer Training School] Dreamt of a Compromise, but 4 Religious Cadets Refused to Listen to Women Singing and Were Expelled. Haaretz. September 9. Available online: http://www.haaretz.co.il/1.1446935 (accessed on 18 October 2015). (In Hebrew).

Harel, Amos. 2012. The General Who Isn't Afraid not to Attack. Haaretz. Available online: http://www.haaretz.co. il/magazine/1.1704114 (accessed on 22 January 2020). (In Hebrew).

Harvey, David. 1973. Social Justice and the City. London: Edward Arnold.

Harvey, David. 1996. Justice, Nature and the Geography of Difference. Oxford: Blackwell.

Hass, Bat sheva, and Hayden Lutek. 2019. Fashion and Faith: Islamic Dress and Identity in The Netherlands. Religions 10: 365. Available online: https://www.mdpi.com/2077-1444/10/6/356/htm (accessed on 25 January 2020). [CrossRef]

Hasson, Nir. 2018. Water Cut to Spring Near Jerusalem to Prevent Female Swimming. Haaretz. Available online: https://www.haaretz.com/israel-news/.premium-water-cut-to-spring-near-jerusalem-toprevent-female-swimming-1.6280253 (accessed on 14 March 2020).

Haynes, Jeffry. 1998. Religion in Global Politics. New York: Longman.

Haynes, Jeffrey. 2005. Religion and International Relations After '9/11'. Democratization 12: 398-413. [CrossRef]

Haynes, Jeffrey. 2006. The Politics of Religion. London: Routledge.

Haynes, Jeffry. 2011. Religion, Politics and International Relations. Selected Essays. London: Routledge.

Hermann, Tamar, Gilad Be'ery, Ella Heller, Chanan Cohen, Yuval Lebel, Hanan Mozes, and Kalman Neuman. 2014. The National-Religious Sector in Israel-2014 Main Findings. Jerusalem: The Israel Democracy Institute.

Hunter, James Davison. 1991. Culture Wars: The Struggle to Define America. New York: BasicBooks.

Janjevic, Darko. 2018. Germans Debate Return of Military Conscription and Service for Men and Women. DW. Available online: https://www.dw.com/en/germans-debate-return-of-military-conscription-and-service-formen-and-women/a-44962067 (accessed on 21 January 2020).

Jobani, Yuval, and Nahshon Perez. 2014. Women of the Wall: A Normative Analysis of the Place of Religion in the Public Sphere. Oxford Journal of Law and Religion 3: 484-505. [CrossRef]

Kampinsky, Aharon. 2005. Religion, Military and Society in Israel: Changes in the Development of the "Rabanut Tsvait". Ph.D. dissertation, Bar-Ilan University, Ramat Gan, Israel. (In Hebrew).

Karmi, Ruth, and Ricky Shapira-Rosenberg. 2012. Strictly Segregated: Mudarot Le'mehadrin. (Strictly Excluded): Separating Women and Men and the Exclusion of Women from the Israeli Public Sphere. Jerusalem: The Reform Center of Religion and State and The Movement for Progressive Judaism, Available online: http://www.reform.org.il/Assets/mudarot.pdf (accessed on 3 November 2015). (In Hebrew) 
Knesset, Protocols. 2010. Urgent Queries: 210. Imprisonment of Religious Cadets Who Left During Women's Singing. In The 170th Session of the Eighteenth Knesset. Jerusalem: The Knesset, pp. 9-17. (In Hebrew)

Kuru, Ahmet. 2007. Passive and Assertive Secularism: Historical Conditions, Ideological Struggles, and State Policies toward Religion. World Politics 59: 568-94. Available online: https://politicalscience.sdsu.edu/docs/ Kuru/Kuru_WP.pdf (accessed on 7 January 2020). [CrossRef]

Lefebvre, Henri. 1991. Critique of Everyday Life. London: Verso. First published 1947.

Lefebvre, Henri. 1991. The Production of Space. Translated by Donald Nicholson-Smith. Cambridge: Blackwell, pp. 289-93. First published 1974.

Levy, Yagil. 2010. The Clash between Feminism and Religion in the Israeli Military: A Multilayered Analysis. Social Politics 17: 185-209. Available online: https://papers.ssrn.com/sol3/papers.cfm?abstract_id=1607523 (accessed on 19 February 2020). [CrossRef]

Levy, Yagil. 2014. The Theocratization of the Israeli Military. Armed Forces E Society 40: 269-94. [CrossRef]

Levy, Yagil. 2016. Religious Authorities in the Military and Civilian Control: The Case of the Israeli Defense Forces. Politics E Society 44: 305-32.

Lewis, Jane. 1992. Gender and the Development of Welfare Regimes. Journal of European Social Policy 2: 159-73. [CrossRef]

Liebes, Tamar, Yoram Peri, and Tsfira Grebelsky-Lichtman. 1996. Where is the Real Influence? The Media and the Alternative Media in Israel's 1996 Elections. Qesher 20: 5-20. (In Hebrew).

Lillevik, Ragna. 2019. The political accommodation of military turbans and the police hijab in Norway: Windows of opportunity. Journal of Ethnic and Migration Studies, 1-17. [CrossRef]

Linder, Roni, and Dan Even. 2013. Israel's Health Ministry to HMOs: Stop Gender Segregation at ultra-Orthodox Clinics. Haaretz. Available online: https://www.haaretz.com/.premium-gender-separation-at-clinics-banned1.5282567 (accessed on 14 March 2020).

Lior, Ilan. 2019. After Exclusion of Women, Toned-down Tel Aviv Holiday Event Canceled. Haaretz. Available online: https://www.haaretz.com/israel-news/.premium-after-exclusion-of-women-toned-downtel-aviv-holiday-event-canceled-1.5447309 (accessed on 19 January 2020).

Low, Setha. 2017. Public Space and the Public Sphere: The Legacy of Neil Smith. Antipode 49: 153-70. [CrossRef]

Luz, Ehud. 1988. Parallels Meet: Religion and Nationalism in the Early Zionist Movement (1882-1904). Philadelphia: Jewish Publication Society of America, (Originally published in Hebrew-Tel Aviv, Am Oved, 1985).

Mancini, Latizia. 2013. Burka, Niqab and Women's Rights. In The Burka Affair across Europe. Edited by Alessandro Ferrari and Sabrina Pastorelli. Surrey: Ashgate.

Mayers, Magen. 2017. New Army Policy OKs Soldiers to Wear Hijabs, Turbans and Religious Beards. Armytimes. Available online: https://www.armytimes.com/news/your-army/2017/01/05/new-army-policy-oks-soldiersto-wear-hijabs-turbans-and-religious-beards/ (accessed on 10 January 2020).

Medina, Jameela. 2014. This Battlefield Called My Body: Warring over the Muslim Female. Religions 5: 876-85. Available online: https://www.mdpi.com/2077-1444/5/3/876 (accessed on 25 January 2020). [CrossRef]

Meir, Avinoam, and Yuval Karplos. 2015. From Total Space to Space Intensity: Intercultural Dynamics of Space Production and its Political Meaning. The Geography Network 8: 40-60. Available online: https://www.academia.edu/16897485/From_Consummate_Space_to_Spatial_Intensity_ Intercultural_Dynamics_of_Production_of_Space_and_its_Political_Significance_in_Hebrew_(accessed on 10 January 2020). (In Hebrew).

Mitchell, Don. 2003. The Right to the City. New York: Guilford.

Motilla, Agustin. 2013. The burqa affair in Spain: Legal perspectives. In The Burka Affair Across Europe. Edited by Alessandro Ferrari and Sabrina Pastorelli. Surrey: Ashgate.

Nahshoni, Kobi. 2010. 'Lamed Heh' memorial march: "The band performed, most of the Pupils left". Ynet. Available online: http://www.ynet.co.il/articles/0,7340,L-3841391,00.html (accessed on 4 November 2015). (In Hebrew).

Nahshoni, Kobi. 2011. Four of the Cadets Who Left during Women's Singing Were Ousted. Ynet. Available online: http://www.ynet.co.il/articles/0,7340,L-4119654,00.html (accessed on 22 January 2020). (In Hebrew).

Németh, Jeremy, and Stephen Schmidt. 2011. The Privatization of Public Space: Modeling and Measuring Publicness, Environment and Planning. Planning and Design 38: 5-23. Available online: https://courses.cit. cornell.edu/sjs96/NemethSchmidt_EPB, \%202011.pdf (accessed on 10 January 2020). 
Orbe, Mark. 1998. Constructing Co-Culture Theory: An Explanation of Culture, Power and Communication. Thousand Oaks: Sage.

Palowski, Jakub. 2015. Lithuania Reintroduces Conscription and Compulsory Military Service. Defence 24. Available online: https:/www.defence24.com/lithuania-reintroduces-conscription-and-compulsory-militaryservice (accessed on 21 January 2020).

Parekh, Bhikhu. 2000. Rethinking Multiculturalism: Cultural Diversity and Political Theory. Houndsmill: MacMillan Press.

Park, Robert. 1984. The City: Suggestions for Investigation of Human Behavior in the Urban Environment. Edited by Robert E. Park and Ernest W. Burgess. Chicago: University of Chicago Press, pp. 1-46. First published 1925.

Pateman, Carole. 1989. Feminist Critiques of the Public/Private Dichotomy. In The Disorder of Women: Democracy, Feminism and Political Theory. Palo Alto: Stanford University Press, pp. 118-40.

Perez, Nahshon. 2019. Religious Rights and Involuntary State Institutions in Democratic Countries: On Evenhandedness and Ecumenism in Militaries. Religions 10: 556. Available online: https://www.mdpi.com/ 2077-1444/10/10/556 (accessed on 20 January 2020). [CrossRef]

Pitkin, Hanna Fenichel. 1981. Justice: On relating private and public. Political theory 9: 327-52. [CrossRef]

Prideaux, Melanie. 2019. Understanding Neighbourhoods as Multifaith Spaces. Religions 10: 500. [CrossRef]

Ravitzky, Aviezer. 1997. Religious and Secular Israelis: A Cultural War? Jerusalem: Position Paper of the Israeli Democracy Institute. (In Hebrew)

Reuters. 2017. Sweden Brings Back Military Draft Amid Concerns Over Russian Aggression. NBC News. Available online: https:/www.nbcnews.com/news/world/sweden-brings-back-military-draft-amidconcerns-over-russian-aggression-n728271 (accessed on 21 January 2020).

Rosenbaum-Rotenberg, Hagit. 2012. Rabbi Eliyahu against women's singing in the IDF. Inn. Available online: https://www.inn.co.il/News/News.aspx/232896 (accessed on 22 January 2020). (In Hebrew).

Rosman-Stollman, Elisheva. 2005. Religion and the Military as Greedy Frameworks: Religious Zionism and the Israel Defense Forces. Ph.D. dissertation, Bar-Ilan University, Ramat Gan, Israel. (In Hebrew).

Rosman-Stollman, Elisheva. 2014. For God and Country? Religious Student-Soldiers in the Israel Defense Forces. Austin: University of Texas Press, Available online: https://scholar.google.com/scholar_lookup?title=For+ God+and+Country?:+Religious+Student-Soldiers+in+the+Israel+Defense+Forces\&author=RosmanStollman, +Elisheva\&publication_year=2014 (accessed on 20 January 2020).

Saar, Yahli, and Nir Kosti. 2009. A phenomenon in IDF units' ceremonies: Female soldiers sing on stage and religious soldiers leave the place. Bamahane 12: 20. (In Hebrew).

Security Service Law, Amendment 21, 2015. Available online: https://main.knesset.gov.il/Activity/Legislation/ Laws/Pages/LawBill.aspx?t=lawsuggestionssearch\&lawitemid=571382 (accessed on 20 February 2020). (In Hebrew)

Shalev, Tal. 2011. Prime Minister: An All-Out War Against Women's Rights Violations. Walla. Available online: http://news.walla.co.il/item/1884699 (accessed on 22 January 2020). (In Hebrew).

Shields, Rob. 1999. Lefebvre, Love and Struggle. London: Routledge.

Shpigel, Noa. 2019. Supreme Court Overrules Okay to Gender Segregation at Afula Event, but Too Late. Haaretz. Available online: https://www.haaretz.com/israel-news/.premium-sex-segregated-concert-in-israel-s-afulathrills-ultra-orthodox-and-their-leaders-1.7685218 (accessed on 19 January 2020).

Simmel, Georg. 2002. The Metropolis and Mental Life. In The Blackwell City Reader. Edited by Gary Bridge and Sophie Watson. Oxford and Malden: Wiley-Blackwell, pp. 11-19. First published 1903.

Smooha, Sammy, and Zohar Lechtman. 2015. Crossing a Red Line: Imposition of a Duty of Civic Service on Arab Youth in Israel. In Mandatory Service or the Duty to Serve? Scenario Analysis of Mandatory Civil Service in Israel. Edited by Yagil Levy. Raanana: Open University of Israel, pp. 121-52. Available online: http://din-online.info/pdf/op26.pdf (accessed on 19 February 2020). (In Hebrew)

Soja, Edward. 1989. Post Modern Geographies: The Reassertion of Space in Critical Social Theory. London: Verso Press. Statman, Daniel. 2019. "Mamlachtiut", Religionization and Religious Soldiers in the IDF. Jerusalem: The Israel Democracy Institute. Policy Paper 139. (In Hebrew)

Statman, Daniel, and Gidon Sapir. 2013. Religion and State in Israel-A Philosophic and Legal Reflection. Haifa: Miskal and Haifa University Press. (In Hebrew) 
Stern, Itai. 2018. An Ultra-orthodox Challenger in 'The Four' Reality Show Refused to Listen to Women's Singing. Haaretz. Available online: https://www.haaretz.co.il/gallery/music/1.6632810 (accessed on 5 March 2020). (In Hebrew).

Tessler, Shmulik. 2007. Songs in Uniform: The Military Entertainment Troupes of the IDF. Jerusalem: Yad Izhak Ben-Zvi Publications. (In Hebrew)

Thompson, Simon. 2019a. The recognition of religion in public spaces. In Recognition and Religion: Contemporary and Historical Studies. Edited by Maijastina Kahlos, Heikki Koskinen and Ritva Palmén. London: Routledge.

Thompson, Simon. 2019b. The expression of religious identities and the control of public space. Ethnicities 19: 231-50. [CrossRef]

Umiel-Feldman, Shani. 2016. The Confluence of Identities in Public Spheres-New Conceptualizations: Women's Singing in Religious Zionism. Ph.D. Dissertation, Bar-Ilan University, Ramat Gan, Israel. (In Hebrew with English Summary).

Vaystoch, Moshe. 2016. Majority in religious Zionism: The IDF Acts Deliberately Against Religious Soldiers. Kippa. Available online: https://www.kipa.co.il/\%D7\%97\%D7\%93\%D7\%A9\%D7\%95\%D7\%AA/\%D7\%A8\%D7\% 95\%D7\%91-\%D7\%91\%D7\%A6\%D7\%99\%D7\%95\%D7\%A0\%D7\%95\%D7\%AA-\%D7\%94\%D7\%93\%D7\% AA\%D7\%99\%D7\%AA-\%D7\%A6\%D7\%94\%D7\%9C-\%D7\%A4\%D7\%95\%D7\%A2\%D7\%9C-\%D7\%91\%

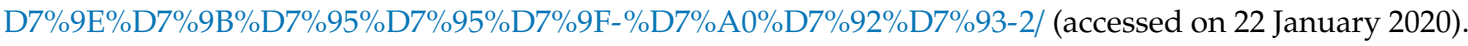
(In Hebrew).

Weintraub, Jeff. 1997. Public/Private: The limitations of a grand dichotomy. The Responsive Community 7: 13-24.

Widdersheim, M. Michael. 2017. Late, Lost, or Renewed? A Search for the Public Sphere in Public Libraries. Information Research 22: 1-18. Available online: http://www.informationr.net/ir/22-1/colis/colis1644.html (accessed on 20 February 2020).

Widdersheim, M. Michael, and Masanori Koizumi. 2016. Conceptual modelling of the public sphere in public libraries. Journal of Documentation 72: 591-610. [CrossRef]

Williamson, Lucy. 2018. France's Macron Brings back National Service. BBC. Available online: https://www.bbc. com/news/world-europe-44625625 (accessed on 21 January 2020).

Yahud, Tomer, and Ariel Finkelstain. 2016. Laws of Employment and Commerce on Rest Days around the World: A Comparative Study. Jerusalem: The Institute for Zionist Strategies, Available online: https://izs.org.il/wp-content/uploads/2016/07/\%D7\%9E\%D7\%97\%D7\%A7\%D7\%A8-\%D7\%9E\%D7\%A9\% D7\%95\%D7\%95\%D7\%94-\%D7\%99\%D7\%95\%D7\%9D-\%D7\%94\%D7\%9E\%D7\%A0\%D7\%95\%D7\%97\% D7\%94-\%D7\%A7\%D7\%95\%D7\%91\%D7\%A5-\%D7\%A1\%D7\%95\%D7\%A4\%D7\%99.pdf (accessed on 20 December 2019) (In Hebrew with English Summary). 